\title{
ASCEZA W ŚWIETLE PISM ŚW. GRZEGORZA WIELKIEGO
}

Istotnym przejawem autentyzmu życia chrześcijańskiego jest duch ascezy. Praktyki ascetyczne propagowały wszystkie wielkie religie. Stanowiły one dla nich albo środek rozwoju człowieka, albo warunek i środek osiągnięcia jedności z Bogiem i świętości religijnej ${ }^{1}$. W znaczeniu fizycznym terainem "asceza" posługiwali się IIerodot, Demokryt, Ksenofont, Platon $i$ oznaczał on wtedy éwiczenia cielesne lub uprawianie jakiejś sztuk1. Ci sani autorzy, a obok nich: Arystoteles, Protagoras, Sokrates, stoicy i inni uźywali tego terminu róvnież w znaczeniu moralnym, w sensie ćwiczenia się w zdobywaniu sprawności, które miały ułatwiać zdobycie mądrości, utożsamianej przez wielu z dobrym postępowaniem moralnym. Znaczenie moralne bardzo często było powiązane z religijnym, które oznaczało praktykowanie pobożności.

Wszystkie te znaczenia słowa "asceza" zna starozytność przedchrześcijańska, a następnie chrześcijańska². Ma teren chrześcijańskiego piśmiennictwa termin "asceza" wprowadzili Klemens Aleksandryjski i Orygenes. Whistorycznym rozwoju rozumienia ascezy ukształtowało się jej pojęcie popularne 1 teologiczne. W sensie popularnym przez ascezę rozumie się różne praktyki umartwień i pokuty, jak również całkowite wyrzeczenie się siebie. Teologicznie przez ascezę rozumie się stałe 1 celowe ćwiczenie się w urzeczywistnianiu doskonałości ludzkiej na podobieństwo Boga, które odwołuje sié nie tylko do wysiłków czysto ludzkich, ale także do laski Bożej ${ }^{3}$.

Według Grzegorza Wielkiego / + 604/ asceza polega na roztropnej rezygnacji z tego, co dozwolone ${ }^{4}$. Do tak pojętej ascezy Grzegrorz

1 Por. W. Słomka, Świętość na świeckiej drodze życia, Poznań-Warszawa, 1981, 198.

2 Tamze, 201.

3 Tamze, 199.

4 Moralia V 11, 17, PL 75, 688: "Solus enim in illieitis non cadit, qui se aliquando et a licitis caute restringit". 
dołącza umartwienia cielesne, które określa terminem "maceratio corporis" ${ }^{5}$. Struktura bytu ludzkiego jest uwarstwiona; jej elementami są: ciało, zmysły, psychika i duch ${ }^{6}$. W dziejach duchowego życia ludzkości, gdzie troska skupiała się na dwóch wyższych regionach istnienia ludzklego, zagadnienie ciała było zawsze trochę żenujące. Wielki przedstawiciel myśli starożytnej Plotyn wstydził się, ze je w ogóle posiada. Asceci pierwszych wieków chrześcijaństwa pod wpływem neoplatończyków oraz myśli wschodniej wypowiadali się o nim na ogół z wielkim niesmakien. Starożytni pisarze ascetyczni uważali za obowiązek, aby poniżać ciało celem wywyższenia ducha ${ }^{7}$. Postawę pionierską zajmuje w tej sprawie Grzegorz Wielki, gdy mówi:

"/.../ trzeba nasz umysł odciaggnąć od przyjenności cielesnej, ale nie trzeba go odwodzić od koniecznej trosk1 o clało"8. "Jeżel1 ktoś lekkomyślnie tak czyni i sadzi może, ze osiaga tą drogą doskonałośc, to przyciśnięty koniecznościa fizyczną - w chorobie czy osłabieniu - będzie musiał zwrócić ciału wszystko, czego mu poprzednio odmówił"9.

Terminy używane przez Grzegorza Wielkiego, jak: "maceratio", "cruciare", "castigare" itp. wcale nie oznaczają środków ani narzędzi tortur cielesnych ${ }^{10}$. Poza jedynym tekstem, który wskazuje na możliwość użycia włosiennłcy 1 popiołu jako środków służących do umartwiania ciała, Grzegorz Wielki nie mówi nigdzie o podobnych okolicznościach ${ }^{11}$. Równiez nie należy utożsamiać zalecanej osobom duchownym przez Grzegorza Wielkiego potrzeby czuwania z wyczerpującą organizm bezsennościa, gdyż może to prowadzić do wysuwania daleko idących i błęlnych wniosków na temat życia ascetycznego

5 Moralia VII 28, 34, PL 75, 785 .

6 Por. S. Witek, Miłość chrześcijańska w życiu człowieka, Warszawa $1983,81$.

7 Tamze.

8 In Fvangelia hom. I 7, 10, PL 76, 845.

9 Epistolae XIII 1, CCL 140 A, 992.

10 Por. 0. M. Porcel, La doctrina monástica de San Gregorio Magno y la "Regula monastica", Washington 1951, 90.

11 Moralia XXXV 6, 7, PL 76, 753; por. 0. M. Porcel, La doctrina, dz.cyt., 97 . 
w tamtych czasach ${ }^{12}$. Kto chce prowadzić życie ascetyczne w prawdziwym tego słowa znaczeniu 1 nie chce utknąć w czystym mechanizmie "ziemskiej aktywności"13, ten powinien, zdaniem Grzegorza, odwrócić się od zła i ćwiczyé się w cnocie ${ }^{14}$. Tych, którzy nie. chcą podjąć się tego, papież porównuje do żołnierzy pragnących tryumfu bez udziału w walce 15 .

Z powyższego wynika, że termin asceza obejmuje u Grzegorza Wielkiego cały obszar życia aktywnego. Nawiazzuje on przez to do tradycji Wschodu, gdzie asceza łączyła się z "theoria"16. Należy podkreśl1ć, że połączenie ascezy z aktywnościq wewnętrzną, jakiego dokonał Grzegorz Wielki, ma charakter wyjątkowy ${ }^{17}$. Wyjątkowość ta polega na tym, że Grzegorz jakkolwiek mówi o "maceratio corpor $1 s^{\prime \prime}$ oraz postach 1 czuwaniach nocnych jako formach życia ascetycznego, to jednak w swych wypowtedziach przywiazuje wiecej uwagi do ascezy duchowej ${ }^{18}$.

Jako doświadczony psycholog zwraca uwagę na niebezpleczeństwo surowej ascezy cielesnej ${ }^{19}$. W trosce o ciało papłeź zaleca zachowanie

12 Por. A. Gillet, Spiritualité et place de moine dans l'Eglise selon saint Grégoire le Grand, w: Théologie de la vie monastique, Paris 1965,335 .

13 Moralia VII 27, 33-34, PL 75, 783-785.

14 Tamże.

15 Moralia VII 28, 34, PL 75, 785: "Esse quippe humiles, sed tamen sine despectu; esse contenti proprils, sed sine necessitate; esse casti, sed sine maceratione corporis; esse patientes, sed sine contumelis volunt; cumque adipisci virtutes quaerunt, sed labores virtutum fugiunt, quid aliud quam et belii certamina in campo nesciunt, et triumphare in urbibus de bello concupiscunt".

16 Por. H. Wójtowicz, Theoria i praxis u Orygenesa, RH 30/1982/ z. 3, 73-79.

17 S. Frank, Actio und contemplatio bei Gregor dem Grossen, "Trierer Theologische Zeitschrift" 78/1969/ 287.

18 In Evangelia hom. II 34, 4, PL 76, 1248.

19 In Ezechielem hom. II 7, 19, PL 76, 1024-1025: "Discamus sat1ar1, ne in sumendis alimentis corporis gulae magis quam necessitati serviamus. Plus enim concupiscentia quam necessitas petit./.../ inde alia tentatio earnis nascitur, dum carni immoderatius in refectione servitur./.../ dum caro fame afficitur, ad cupiditatem animus 1rritetur $/ \ldots / n$. 
właściwych proporcj120. Dlatego - zdaniem Grzegorza - sztuka jest utrzymać własne ciało w takim stanie, aby mogło z jednej strony służyć człowiekowi w spełnianiu dobrych dzieł, z drugiej zaś odwodzić go od tego, co nikczemne 1 haniebne ${ }^{21}$.

Powyższa zasada koreluje z wprowadzona przez Bazylego do systemu ascezy chrześcijańskiej stoicką zasadą "miary potrzeb"22, jak również z zasadą "roztropnej rezygnacji" przejętej od Kasjana 23. Doświadczony życiowo Grzegorz mówi, że prawdziwa asceza nie polega na umartwientach wyszukanych przez nas, lecz na pokornym przyjmowaniu tych umartwień, którymi jesteśmy doświadczeni przez Boga. Te doświadczen1a, jakie Bóg na nas dopuszcza, Grzegorz określa wspólną nazwą "flagella Dei"24. Tak rozumiana asceza moze przejawiać się w cierplıwym znoszeniu chorób, krzywd, a także niesprawiedliwej i złej władzy państwowej, na co skarżł się także 1 Grzegorz Wielki, kiedy mówił, ze sam znosi "w cierpliwym posłuszeństwie cięzar głupiej władzy m Bizancjum"25. Podkreśla ọn, że "Plagella Dei" są czymś nieodłącznym od życia ludzkiego, które jest jednym "Wielkim Piątkiem", gdyż przebiega w boleśclach 1 naznaczane bywa c1ęzarem krzyza ${ }^{26}$. W tym miejscu papież zaleca naśladować cnotę cierpliwości 1 łagodności, jakimi odznaczał się Chrystus ${ }^{27}$. W praktykowaniu takiej formy ascezy Grzegorz Wielk1 wysuwa na pierwsze miejsce cnote pokory 28. Tak pojęta asceza prowadzi człowieka do kontemplacji wiecznej ojczyzny 29

20 Tamże, 1025: "Si igitur ei plus quam debemus tribuimus, hostem nutrimus. Et si necessitati eius quae debemus non reddimus, c1vem necamus".

21 Tanże: "Sat1anda itaque est caro, sed ad hoc usque, ut in bono nobis opere famulari sufficiat. Nam quisquis ei tantum tribuit, ut superbiat, satiari penitus ignorat. Ars 1taque magna est satiart, ne unusquisque per satietatem carnis ad iniquitatem prorumpat turpitudinis".

Basilius, Regulae fusius tractatae 18, PG 31, 965.

23 Cassianus, Collatio II, S,Ch 42, $109 \mathrm{n}$.

24 Por. Gillet, Spiritualité et píace, dz.cyt., 337.

25 Por. E. Caspar, Gregor der Grosse, w: Meister der Politik, Stuttgart 1923, Bd. 1, 468-478.

26 In Ezechielem hom. II 4, 2, PL 76, 973.

27 Tanze: "Modo enim quisquis per flagella corripitur, et correptionibus emendatur, in mansuetudine corripitur, non in ira".

28 Moralia XXIII 13, 24, PL $76,265$.

29 Moralia XXIII 21, 41, PL 76, 276. 
Ukierunkowanie aktualnego życia na przyszłe Królestwo Boże nie jest bynajmniej propagowaniem ideału monastycznego, dostępnego tylko nielicznym. Bóg, zdaniem Grzegorza, kreśląc przed człowiekiem eschatyczną wizję przyszłości, uczynił ją możliwą do osiągnięcia zarówno dla ludzi świeckich jak i duchownych:
"Wszystkie te trzy stany mają tę samą miarę/.../ 1 choć istnieje między nimi wielka rozpiętość zasług, nie ma żadnej różnicy we wierze, która je ożyia /.../, gdyż ostatecznej nagrodzie, mimo róznicy jedności, dla wszystkich będzie jedno życle szczęśliwe /.../. Bez wątpienia jeden będzie się cieszył więcej, niz drugi, ale jedna to będzie radość płynąca z widzenıa swego Stwórcy"30.

Choclaz asceza, Jako droga prowadząca do zjednoczenia się człowieka z Bogiea, jest zalecana przez Grzegorza wszystkim trzem stanom, jakie wyróżnił, to jednak w szczególny sposób obowiązuje ona kapłanów. Kapłan, jako naśladowca Chrystusa, powinien nieść krzyż dla współzbawiania siebie i drugich. Kapłan, który szczerze dązy do prawdziwej świętości, nie tylko ma trzymać się z dala od tego, co jest zakazane, ale winien także umieć odmówić sobie tego, co jest dozwolone 31 . Fedług Grzegorza Wielkiego asceza zewnętrzna /umartwienia cielesne/ nigdy nie powinna zająć miejsca ascezy wewnętrznej/umartwienia duchowe/. W życiu duchowym asceza zewnętrzna oderwana od ascezy wewnętrznej byłaby nawet szkodliwa, gdyż napełniałaby duszę człow1eka poczuciem samowystarczalności 1 próżnej chwały ${ }^{32}$.

Grzegorz Wielki i tu ujawnia się, jak widać, jako zwolennik zachowania właściwych proporcji między dwiema formami ascezy, co stanowi nieodzowny element życia duchowego. Mówiąc o konieczności związku, jaki powinien zachodzić między ascezą zewnętrzną 1 ascezą wewnętrzną, papieź podkreśla, że ten drugi rodzaj ascezy również dysponuje środkam1, które ze swej natury są duchowe. Należą tu: umiejęt-

30 In Ezechielem horn. II 4, 6, PL 76, 977 .

31 Dialogi de vita et miraculis patrum italicorum IV 11, PL 77, 336: "Święci mężowie to mają sobie właściwe, że, aby byćc dáloko od tego, co jest zakazane, często odmawiają sobie tego, co jest dozwolone".

32 Moralia VIII 44, 72, PL 75, 845; Regula pastoralis III 19, PL 77 , 82. 
ność życia w samotności i we wspólnocie, pokora, brak pychy 1 wyntosłości ${ }^{33}$ a także duch ubóstwa ${ }^{34}$.

Postawą prawdziwie ascetyczną, według Grzegorza, jest nie tyle poszukiwanie cierpienia, co jego akceptacja. Ten,kto pokornie przyjmuje "Plagella Dei", o których mówi papież, może tą drogą odbyć pokutę $i$ doznać oczyszczenia ${ }^{35}$. Tak pojęta asceza pozwala człowiekowi zapanować nad sobą a nawet poświęcić się w zupełności sprawie Bozej ${ }^{36}$; rozwija w nim cnotę czystości ${ }^{37}$, wzmaga miłość do Boga i bliźniego ${ }^{38}$, staje się przyczyną umiłowania rzeczy niebieskich orazkształtuje w nim poczucie prawdy ${ }^{39}$.

Na koniec należy podkreślić, że w przeciwieństwie do przedchrześcijańskich autorów pism ascetycznych, Grzegorz Wielk1 zwraca uwage na konieczność zależnośc1 wszelkich ludzkich dążé́ ascetycznych od łaski Bożej, która te dążenia inspiruje 1 nimi kieruje ${ }^{40}$. Asceza rozumiana przez Grzegorza Wielkiego jako forma życia aktywnego nie polega tylko na roztropnej rezygnacji z tego, co dozwolone $i$ unikaniu zła, lecz w swej strukturze zawiera także element pozytywny, a jest nim przeciwstawianie się złu, które powoduje 1 rozwija osobistá świętość u tego, kto ją praktykuje.

Podsumowując wypowiedzi Grzegorza Wielkiego na temat ascezy należy stwierdzic, że papleż rozpatruje to zagadnienie na płaszczyźnie dobrowolnej 1 roztropnej rezygnacji z tego, co dozwolone. Na

33 Por. Gillet, Spiritualité et place, dz.cyt., 337.

34 Moralia X 31, 52, PL 75, 950-951: "/.../ quisquis,stimulo divini amoris excitatus, hic possessa reliquerit, /.../ sese spontanea p a $u$ p e r a $t$ e c a s t 1 g a t"; por. Moralia XXXIV 3, 56, PL 76, 719-721.

35 Eplstolae II 35, CCL 140, 120; por. Porcel, La doctrina monástica, dz.cyt., 88 .

36 Epistolae IX 111, CCL 140 A, 664: "Mądrze bowiem przezwycięża pokusy do rzeczy niedozwolonych ten, kto nauczył się nie korzystać nawet z dozwolonych"; por. Porcel, La doctrina monástica, dz.cyt., 97 .

37 Epistolae I 24, CCL 140, 25: "/.../ tunc castimonia ad perfectum munditiae candorem ducitur, cum per abstinentian caro fatigatur".

38 Tamże: "Sed cum mens ad praecepta caritatis tenditur, restat procul dubio, ut per abstinentiam caro maceretur".

39 Tamże.

40 Moralia XVIII 43, 70, PL 76, 79; por. Gillet, Spiritualité et place, dz.cyt., 335 . 
uwage zasługuje tu oryginalne ujęcle ascezy jako drogi o charakterze oczyszczającym, zawierającej w swej wewnętrznej strukturze element pozytywny, jakim jest obowiazzek ćwiczenia się w doskonałościach moralnych oraz element negatywny rozumiany jako clerpliwe 1 konsekwentne przeciwstawianie sie złu. W przeciwieństwie do autoróm przedchrześcijańskich, Grzegorz uzależnia wszelkie osiagnięcia na tej drodze zycia nie tylko od osobistych wysiłków człowieka, ale przede mszystkim od łask 1 Bożej, która inspiruje 1 podtrzymuje wszelkie dqżenia na tej płaszczyźnie źycia. Jest to niemal nowoczesne ustawienie ascezy chrześcijańskiej w ramach doskonalenia ciała 1 ducha, wprowadzenie w zycie ludzkie równowagi pełnej mądrości, która pierwszeństwo przyznaje ascezle ducha nie lekceważąc ciała.

$$
\text { Ks. Stanisław Sojka - Tarnów }
$$

\section{DE ASCESI IN SCRIPTIS SANCTI GREGOHII MAGNI /Argumentum/}

Hac in dissertatiuncula Gregoriana notio ascesis late explanatur, quae prudens abstinentia a licitis habetur. 